\title{
Potential effect of hyaluronic acid and triamcinolone acetate, alone or combined, on chondrogenic differentiation of mesenchymal stem cells
}

\author{
Efecto potencial del ácido hialurónico y del acetato de triamcinolona solos o combinados sobre la \\ diferenciación condrogénica de células-tronco mesenquimales \\ Efeito potencial do ácido hialurônico e triancinolona acetonida, isolados e combinados, na diferenciação \\ condrogênica de células-tronco mensenquimais
}

\author{
Pablo E Ocampo $^{l}$ (D); Viviana Vallejo ${ }^{l}$ (D); Luis M Montoya ${ }^{2}$ iD; Noeme S Rocha ${ }^{l}$ iD; \\ Fernanda da C Landim ${ }^{l}$ (D); Sheila C Rahal ${ }^{l *}$ (D).
}

${ }^{1}$ São Paulo State University (Unesp), School of Veterinary Medicine and Animal Science, Botucatu.
${ }^{2}$ Faculty of Veterinary Medicine, Universidad Nacional de Colombia, Bogotá, Colombia, Research Group in Veterinary Pathology.

To cite this article:

Ocampo PE, Vallejo V, Montoya LM, Rocha NS, Landim FdC, Rahal SC. Potential effect of hyaluronic acid and triamcinolone acetate, alone or combined, on chondrogenic differentiation of mesenchymal stem cells. Rev Colomb Cienc Pecu 2021; 34(3): 212-223. DOI: https://doi.org/10.17533/udea.rccp.v34n3a06

\section{Abstract}

Background: Osteoarthritis is a complex degenerative disease with several factors contributing to joint damage. Objective: To compare the potential effect of hyaluronic acid (HA) and triamcinolone acetonide (TA), alone or combined, on the in vitro chondrogenic differentiation process of mesenchymal stem cells (MSCs). Methods: MSCs were divided into four groups: Control, HA, TA, and HA/TA combined. Each treatment group was cultured for 14 days in chondrogenic differentiation medium. The chondrogenic differentiation potential was assessed by histology and immunohistochemistry. Results: The HA and HA/TA-treated MSCs presented histological characteristics similar to native chondrocytes. The extracellular matrix (ECM) of TA-treated MSCs was compact and organized. Glycosaminoglycan staining was intense in Control, moderate in TA, slight in HA/TA, and undetectable in HA. Type II collagen immunoreactivity was high in the TA-treated ECM and MSCs. Conclusions: Histological analysis shows that HA influences morphological development similar to chondrocytes of the MSCs, but with low expression of specific cartilage molecules. The TA promotes formation of a compact and organized ECM.

Keywords: cell differentiation; cartilage; chondrocytes; chondrogenesis; chondrogenic differentiation; collagen; corticosteroids; glucocorticoid; histology; hyaluronic acid; mesenchymal stem cell; osteoarthritis; triancinolone acetonide; viscosupplementation.

Received: June 9, 2020; accepted: August 19, 2020

*Corresponding author. Rua Prof. Doutor Walter Mauricio Correa. Botucatu-SP, Brazil. Tel.: +(055)14-38802041.

E-mail: sheila.canevese-rahal@unesp.br 


\section{Resumen}

Antecedentes: La osteoartritis es una enfermedad degenerativa compleja en la cual varios factores contribuyen al daño articular. Objetivo: Comparar el efecto del ácido hialurónico (HA) y acetónido de triamcinolona (TA), solos o en combinación, en el proceso de diferenciación condrogénica in vitro de células madre mesenquimales (MSCs). Métodos: Las MSCs fueron divididas en cuatro grupos: Control, HA, TA y HA/TA, y cultivadas por 14 días en medio de diferenciación condrogénica para cada tratamiento. El potencial de diferenciación condrogénica fue analizado por medio de histología e inmunohistoquímica. Resultados: Las MSCs tratadas con HA y HA/TA, presentaron características histológicas similares a los condrocitos nativos, y la matriz extracelular (ECM) de MSCs tratadas con TA fue más compacta y organizada. La tinción de glicosaminoglicanos fue intensa en el Control, moderada en TA, ligera en HA/TA, y sin tinción en HA. La inmunoreactividad para colágeno tipo II fue más alta en las MSCs y ECM tratadas con TA. Conclusión: El análisis histológico muestra que el HA influencia un desarrollo morfológico similar a los condrocitos de las MSCs, pero con baja expresión de moléculas específicas de cartílago. La TA promueve la formación de una ECM compacta y organizada.

Palabras clave: acetato de triamcinolona; ácido hialurónico; cartílago; condrocitos; condrogénesis; colágeno; corticosteroides; célula madre mesenquimal; diferenciación celular; diferenciación condrogénica; glucocorticoide; histología; osteoartritis; viscosuplementación.

\section{Resumo}

Antecedentes: A osteoartrite é uma doença degenerativa complexa, na qual vários fatores contribuem ao dano articular. Objetivo: Comparar o efeito do ácido hialurônico (HA) e Triancinolona acetonida (TA), só ou combinado no processo de diferenciação condrogênica in vitro de células tronco mesenquimais (MSCs). Métodos: MSCs foram divididas em 4 grupos: Controle, HA, TA y HA/TA e cultivadas por 14 dias com meio de diferenciação condrogênica e seus respectivos tratamentos. O potencial de diferenciação condrogênica foi acessado por meio de histologia e imunohistoquímica. Resultados: Histologicamente, MSCs tratadas com HA e HA/TA apresentaram características semelhantes de condrócitos nativos, e a matriz extracelular de MSCs tratadas com TA foi mais compacta e organizada. A coloração para glicosaminoglicanos foi intensa no Controle, moderada no TA, leve no HA/TA e sem coloração com HA. Para os grupos tratamento, a imunoreatividade para colágeno tipo II foi maior nas células e matriz extracelular tratadas com TA. Conclusão: Mediante análise histológica, o HA influenciou o desenvolvimento morfológico semelhante a condrócitos das MSCs, mas com baixa expressão de moléculas específicas de cartilagem. A TA promoveu a formação de uma matriz extracelular compacta e organizada.

Palavras-chave: ácido hialurônico; cartilagem; colágeno; condrócitos; condrogênese; corticosteroides; célula-tronco mesenquimal; diferenciação celular; diferenciação condrogênica; glicocorticoide; histologia; osteoartrite; triancinolona acetonida; viscosuplementação. 


\section{Introduction}

Osteoarthritis (OA) has a global impact with significant economic losses in the animal population, especially among dogs and horses, as well as humans (Fox, 2010; McIIwraith et al., 2012). It is recognized as a worldwide public health problem generating disability and contributing to mortality in elderly humans. (March et al., 2016). The disease is characterized by degeneration of not only articular cartilage with different degrees of matrix fibrillation, fissure, ulceration and loss of thickness, but also other articular tissues, such as synovial membrane and subchondral bone, thus participating in the progression of $\mathrm{OA}$ (McIlwraith et al., 2012).

Treatment of OA poses a challenge because it needs to reduce joint inflammation and prevent damage, or to repair damaged cartilage tissue, in order to recover the characteristics of the original cartilage (Goodrich and Nixon, 2006; Goldring, 2012). Since there is currently no curative therapy, the treatment goals are pain relief and improvement of joint function. Pharmacological treatment options include nonsteroidal antiinflammatory drugs, analgesics and intraarticular administration of corticosteroids and HA (Goldberg and Goldberg, 2010; McIlwraith et al., 2012).

Intra-articular corticosteroids are considered potent anti-inflammatory agents that suppress the immune response. However, their use remains controversial, based on their possible deleterious effects on cartilage (McIlwraith, 2010; Pekarek et al., 2011; Mcllwraith et al., 2012). According to a study, intraarticular injection (IA) of steroids supplied every 12 weeks for two years in human patients with OA showed that cartilage loss and pain improvement did not differ from a placebo (Hart, 2017). Thus, its use is limited to improve the acute clinical setting (Majeed et al., 2018).

Triamcinolone acetate, triamcinolone hexacetonide, and methylprednisolone acetate are long-acting corticosteroid preparations frequently used intra-articular in human patients (Silvinato and Bernardo, 2017). The efficacy of one corticosteroid over the other remains controversial (Golding et al., 2017). However, a systematic review suggests that triamcinolone induces greater pain reduction in knee osteoarthritis compared to methylprednisolone or betamethasone (Hepper et al., 2009).

In turn, the use of IA HA for management of OA has increased. The exact mechanism of action at the cellular level is not fully understood (Goldberg and Goldberg, 2010; Legré-Boyer, 2015), but pain reduction has been related to effects on peripheral pain receptors and viscoelastic properties of synovial fluid (Goldberg and Goldberg, 2010). The antiinflammatory effects have been associated with reduced chemotaxis and phagocytosis of neutrophils activated by HA-CD44 interactions, as well as increased synthesis of high-molecularweight HA by synoviocytes (Goodrich and Nixon, 2006). Currently, due to lubricating, anti-inflammatory and chondroprotective properties, new products are being developed based on HA and / or together with other synergistic drugs (Bowman et al., 2018). In addition, a combined use of corticosteroids and HA has been proposed to obtain the immediate anti-inflammatory action of corticosteroid and long-term chondroprotective effects of HA (Mcllwraith et al., 2012; Legré-Boyer, 2015).

Thus, the present study aimed to compare the effects of HA and TA, alone or combined, on the in vitro chondrogenic differentiation process of MSCs. The hypothesis is that HA and TA promote better in vitro chondrogenic differentiation of equine MSCs compared with the Control.

\section{Materials and Methods}

\section{Ethical considerations}

All procedures were approved by the Ethics Committee of the School of Veterinary Medicine and Animal Science from São Paulo State University "Júlio de Mesquita Filho", UNESP, Botucatu (no. 0049/2017 - CEUA). The products were obtained from the Life Technologies Corporation, Carlsbad, CA, USA, unless otherwise stated. 


\section{Bank cells, thawing and culture of MSCs}

EquineMSCs frombonemarrow offiveanimals aged less than 10 years previously characterized by flow cytometry from a cell bank were seeded in culture flasks $\left(175 \mathrm{~cm}^{2}\right)$. Each flask contained $1 \times 10^{6}$ cells and $15 \mathrm{~mL}$ of maintenance medium (MM) with 90\% Dulbecco's Modified Eagle Medium (DMEM/F12), 10\% fetal bovine serum (FBS), $1.5 \%$ penicillin-streptomycin (PenStrep), $1.2 \%$ amphotericin $\mathrm{B}$ (fungizone) and $0.1 \%$ Amikacine. Before the experiment, a test was performed to determine the ideal concentration and growth curve to define the differentiation day using two different concentrations.

\section{Chondrogenic differentiation in microtube}

Samples of MSCs at the third passage were placed into 12 microtubes at the final concentration of $5 \times 10^{5}$ cells/microtube. The MSCs were cultured in MM for 48 hours, then transferred to a chondrogenic differentiation medium (DM) that was prepared according to the manufacturer's recommendations. Additionally, the DM was supplemented with $1.2 \%$ Fungizone and $1.5 \%$ PenStrep.

Once the differentiation was underway, the microtubes were equally divided into 4 treatment groups (each group in technical triplicate): Control, HA (10\%) (Termofrio Laboratory, São Carlos, SP, Brazil), TA, and HA/TA (Table 1). The concentrations of the drugs were based on previous studies (Siengdee et al., 2015; Wernecke et al., 2015). Each microtube had $5 \times 10^{5}$ cells per $500 \mu \mathrm{L}$ of differentiation medium and its respective treatment. The samples were centrifuged at $600 \mathrm{~g}$ for 5 minutes and incubated at $37{ }^{\circ} \mathrm{C}$ and $5 \% \mathrm{CO}_{2}$ for 14 days. The DM with each treatment was replaced every 72 hours.

Table 1. Experimental groups and their treatments, differentiation medium (DM), hyaluronic acid (HA), triamcinolone acetonide (TA).

\begin{tabular}{lc}
\hline Group & Dose \\
\hline Control & $\mathrm{DM}$ \\
$H A$ & $\mathrm{DM}+2.5 \mathrm{mg} / \mathrm{mL}$ \\
$T A$ & $\mathrm{DM}+0.2 \mathrm{mg} / \mathrm{mL}$ \\
$H A / T A$ & $\mathrm{DM}+2.5 \mathrm{mg} / \mathrm{mL}+0.2 \mathrm{mg} / \mathrm{mL}$ \\
\hline
\end{tabular}

\section{Histological and immunohistochemical (IHC) evaluations}

After culturing, the pellets were processed for histological analysis. Sections were stained with hematoxylin-eosin (H\&E), Alcian blue (AB) $(\mathrm{pH}$ 2.5) and toluidine blue (TB), and IHC for type II collagen was conducted.

The IHC samples were evaluated for the presence of type II collagen in the cytoplasm and ECM. Histological sections of $4 \mathrm{~mm}$ were obtained from the pellets in positive charged slides (Amitel ${ }^{\circledR}$ ), which were placed 15 minutes on the stove at 60 ${ }^{\circ} \mathrm{C}$, deparaffinized in xylene, and rehydrated in decreased ethanol concentrations. After washing under running water for 5 minutes, the sections were exposed to heat in a pressure cooker with citrate buffer solution $(\mathrm{pH} 7.0)$ at $125{ }^{\circ} \mathrm{C}$ for 25 minutes in order to induce them to epitope retrieval. Blocking of endogenous peroxidase was performed with PBS $+3 \%$ hydrogen peroxide in dark luminescence for 30 minutes. Then, the sections were washed in a Tris solution with $\mathrm{pH}$ 7.4. Nonspecific ligation sites were blocked with a 3\% solution of nonfat dry milk for 60 minutes. Sections were then incubated (overnight) by using primary antibody (1:300 type II collagen, Anti-Collagen II ab34712, Abcam, Cambridge, MA, USA). Second incubation was performed with the secondary antibody $(1: 300$, polyclonal goat anti-rabbit IgG-HRP p0448, Dako) for 90 minutes. The slides were revealed with chromogen 3,3'-diaminobenzidine (DAB), and counterstained by using Harris hematoxylin.

The IHC analysis was carried out independently by two researchers. The samples were evaluated semi-quantitatively as follows: $1: \leq 25 \%$ of labeled cells, $2: 26-50 \%, 3: 51-75 \%$ and $4: \geq 75 \%$; which were considered respectively: 1) unstained, 2) slightly stained, 3) moderately stained, and 4) intensely stained (Amaral, 2005). The total number of cells from five fields were randomly counted. The images were captured by an optical microscope (Zeiss ${ }^{\circledR}$, Germany) with 40x objective lens. The captured images were analyzed using the AxioVision 4.8 software. 


\section{Statistical analysis}

The Kolmogorov-Smirnov method was employed to assess normality. The reliability of IHC measurements taken by the researchers was analyzed by an unpaired Student's $t$ test. Oneway ANOVA was used for comparison among four groups. Tukey was used as post-hoc test. Differences were considered statistically significant when $\mathrm{p}<0.05$.

\section{Results}

\section{Cell and pellet evaluation}

Cell viability was $\geq 80 \%$. Adhesion to the flask was obtained at 48 hours. Fibroblastoid morphology was visualized after five days of culturing and reached $80 \%$ confluence in 11 days. Macroscopically, the concentration of $1 \times 105$ cells generated a $2 \mathrm{~mm}$ diffuse pellet, while that of $5 \times 10^{5}$ cells generated a $4 \mathrm{~mm}$ consistent pellet (Figure 1).

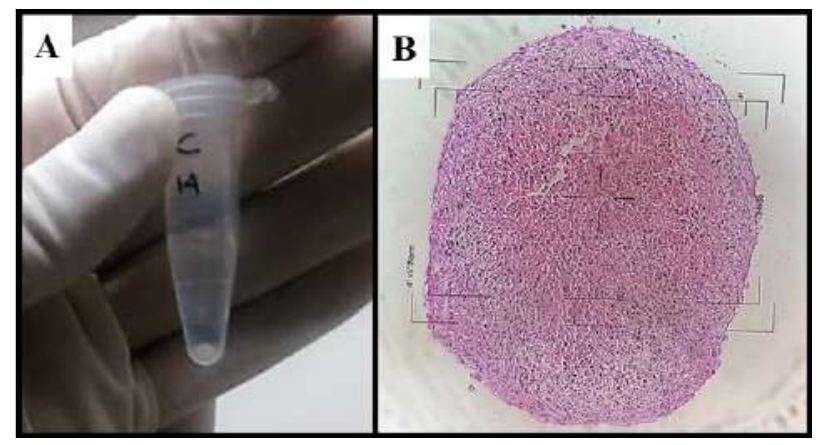

Figure 1. Macroscopic (A) and microscopic (B) (10X) views of the resulting pellet obtained at a concentration of $5 \times 10^{5}$ cells after two days of culturing with MM.

\section{Macroscopic evaluation}

In the HA and HA/TA groups the pellet underwent conformation loss, and spread at the bottom of the microtubes. The control and TA group maintained the compact and homogeneous pellet shape. In all groups, there was no visible pellet growth.

\section{Histological and IHC evaluations}

The HA/TA Group showed a cellularity increase compared to the others (Figure 4). The
HA/TA Group and more specifically the HA Group showed rounded cells located within the lacunae. Nevertheless, the control and TA groups did not exhibit chondrocyte-like morphology. The round nuclear shape predominated in the cells of all groups. The ECM presented a homogeneous and compact aspect, which appeared more intense in the Control and TA groups (Figure 2).

The TA Group presented moderate production of Glycosaminoglycan compared to the Control Group. Glycosaminoglycan production was mild in the HA/TA and not detectable in the HA Group. In turn, the Control Group showed intense staining (Figure 3).

There were no statistically significant differences for IHC measurements taken by the researchers $(p \geq 0.7331)$. As to the percentage of cells stained by IHC, intense staining was poorly represented. The Control Group was moderately stained, TA and HA groups were slightly stained while the HA/ TA group was unstained (Figures 4 and 6). For all groups, the highest percentage of stained cells had a slight staining intensity. Furthermore, the TA Group had the highest percentage of intensely stained cells when compared to the other groups (Figure 5).

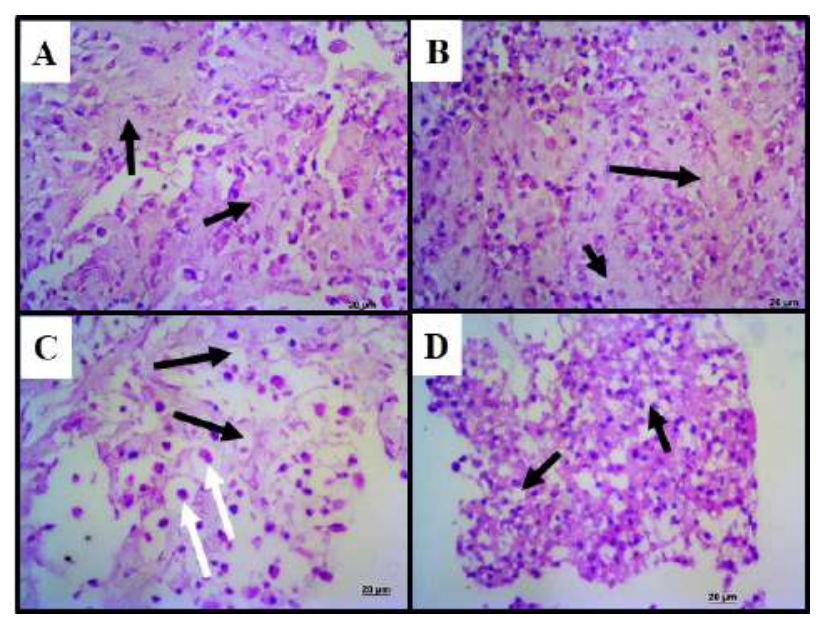

Figure 2. Cellular histomorphology. (A) Control showing the presence of ECM (black arrow) surrounding fibroblast-like cells and a few rounded cells. (B) TA Group displaying increased cellularity and presence of some rounded cells with eosinophilic cytoplasm and abundant ECM (black arrow). (C) HA Group showing ECM and discrete number of chondrocyte-like cells (white arrow) within lacunae (black arrow). (D) HA/TA Group presenting small amount of ECM and chondrocyte-like cells (black arrow) located within lacunae. H\&E staining. 
However, there were no statistically significant differences among groups $(\mathrm{p}=0.8190)$.

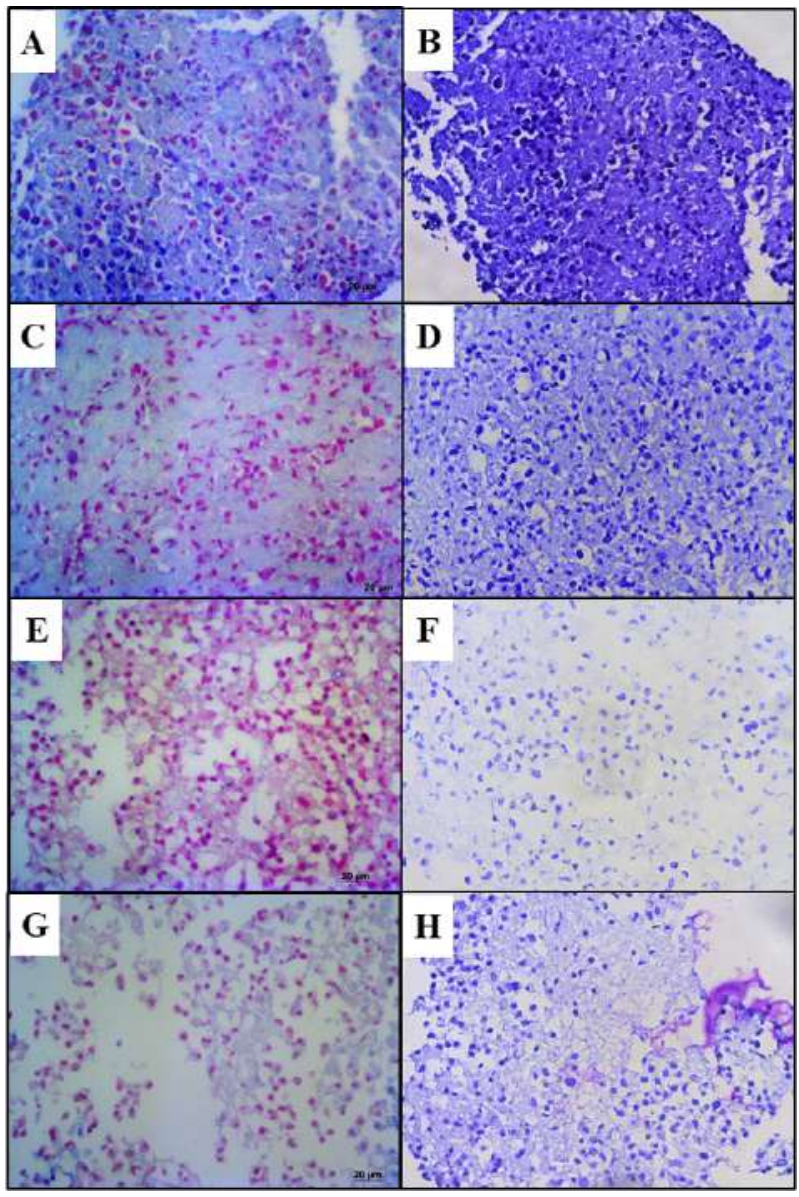

Figure 3. Glycosaminoglycan detection by AB (left column) and TB (right column) (A-B) Control showing intense staining. (C-D) TA Group with moderate staining. (E-F) HA Group with no staining. (G-H) HA/TA Group with slight staining.

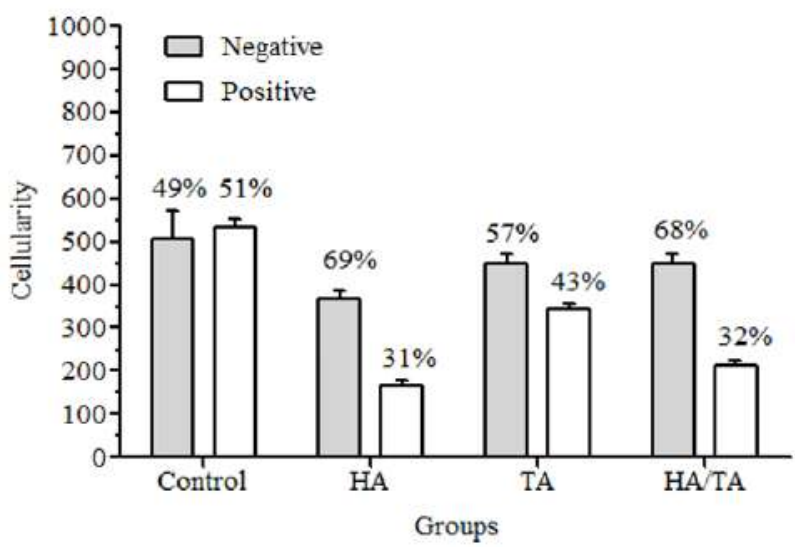

Figure 4. IHC evaluation for type II collagen (cellularity and immunoreactivity) according to cell-treatment group. Values are expressed as mean \pm standard deviation.

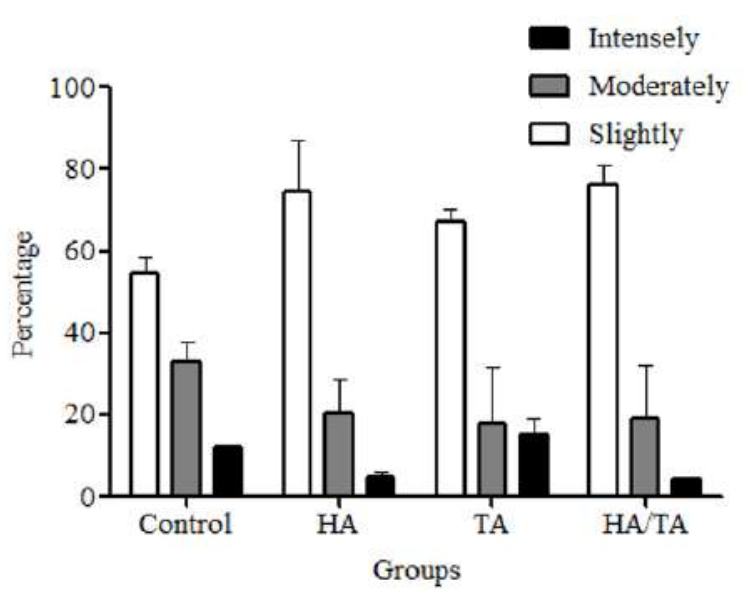

Figure 5. Immunoreactivity percentage of type II collagenpositive cells in cell-treatment groups according to staining intensities. Values are expressed as mean \pm standard deviation.

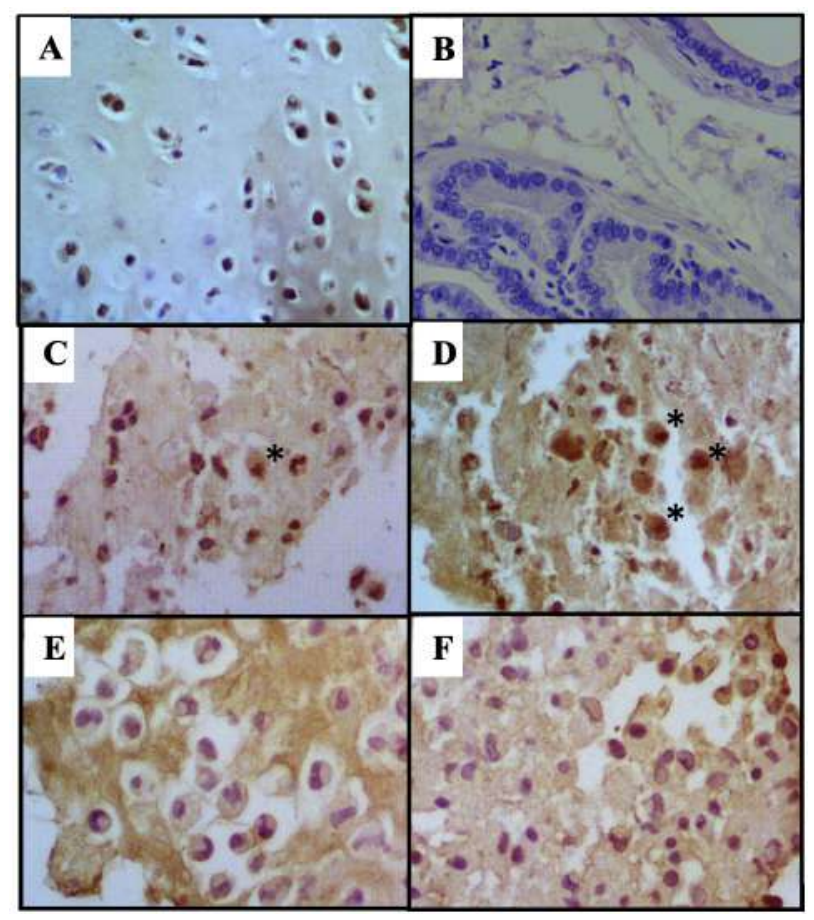

Figure 6. IHC for type II collagen for cells (A) Positive control: Articular condrocytes (B) Negative control: Prostate (C) Control with moderate staining. (D) TA group with slight staining (*field with few intensely stained cells). (E) HA group with slight staining and, (F) HA/TA group considered unstained. 100x.

The ECM of the HA Group and more specifically the HA/TA Group were more intensely stained than TA and Control groups. (Figure 7). Non-specific staining results were discarded. 
Table 2. Immunohistochemistry score for type II collagen according to extracellular-matrix treatment groups.

\begin{tabular}{lc}
\hline Group & Score* $^{*}$ \\
\hline Control & 2 \\
$H A$ & 2 \\
$T A$ & 2 \\
HA/TA & 3 \\
\hline
\end{tabular}

*Score: $1=$ unstained; $2=$ slightly stained; $3=$ moderately stained; $4=$ intensely stained.

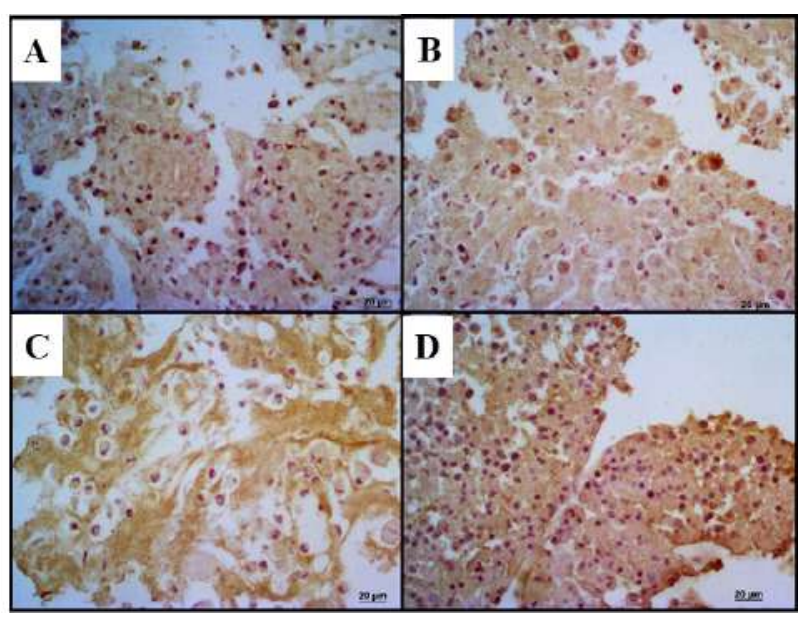

Figure 7. IHC for ECM type II collagen (A) Control Group with slight staining. (B) TA Group with slight staining, (C) HA Group with moderate staining and, (D) HA/TA Group with intense staining.

\section{Discussion}

Each of the several in vivo models, in vitro experimental systems and testing of intraarticular medication present its own advantages and disadvantages (Jo et al., 2014; Mak et al., 2016; Grodzinsky et al., 2017). In the present study we chose the cell-culture testing because of the possibility of microenvironmental control, characterization, homogeneity of the samples, and in vitro modeling of in vivo conditions (Freshney, 2010).

In order to obtain material with a phenotype similar to native articular cartilage, the pellet culture system was chosen. This system allows cell-to-cell interaction, similar to the precartilage condensation of stem cells during embryonic development (Yang et al., 2004; Bhumiratana et al., 2014), and increases the efficiency of cell seeding and formation of
ECM rich in type II collagen (Larson et al., 2002). However, some authors have reported that MSCs cultured and differentiated in a pellet system do not always present a chondrocyte phenotype, but rather express some specific markers of hypertrophic tissue. This affirmation was corroborated in the present study, in which only the HA Group showed the positive phenotype. Despite disagreement among some researchers, this system has been recommended for clinical use and for elucidating details about chondrogenesis in the early stages (Yang et al., 2004).

MSCs subjected to chondrogenic differentiation in a pellet culture system, in general, have a decreased proliferation rate (Baksh et al., 2004). Thus, to guarantee a sufficient number of MSCs for the evaluations, the present study used a high cell concentration, which was determined based on the pellet culture test. Similar concentrations were employed in studies that differentiated MSCs isolated from different sources into chondrocytes, adipocytes and osteocytes (Lovati et al., 2011; Schuurman et al., 2016).

Macroscopically, the loss of pellet conformation that occurred in the HA and HA/ TA groups are probably related to viscosity and dense consistency of HA. A crosslinked HA with molecular weight of $6,000 \mathrm{kDa}$ was used in the present study. There is heterogeneity in the estimates of HA efficacy among the studies, but high-molecular-weight HA seems more effective (Lo et al., 2003; Wang et al., 2004). Histologically, only cells in HA and HA/TA groups exhibited chondrocyte-like morphology, including round-shaped cells located in lacunae (McGeady et al., 2017). Probably, the hydrophobic capacity of HA that provides a stiffness and viscous consistency of the medium favored a better cellular differentiation. Other studies have found that the use of scaffolds composed of HA may favor chondrogenic differentiation of MSCs (Awad et al., 2004; Matsiko et al., 2015). The cells of control and TA groups did not exhibit chondrocyte-like morphology. A homogeneous 
ECM and some round cells inside lacunae were observed in the HA/TA group. The HA group presented scant ECM surrounding a large number of round cells inside lacunae. A decrease in chondrogenic differentiation of MSCs cultured in hydrogel without HA or HA mixed with other compounds was also observed in a study using umbilical-cord-blood-derived MSC composites and four types of hydrogels (Chung et al., 2014).

Glycosaminoglycan production assessed by $\mathrm{AB}$ staining was decreased in all the groups compared to the Control. The moderate response in the TA Group probably was influenced by the time of exposure to the corticosteroid. An in vitro study on chondrocytes from dogs exposed to TA at different time-points concluded that continuous exposure to TA slightly reduced Glycosaminoglycan (14 days), which was attributed to corticosteroid receptor downregulation (Jansen et al., 2016). On the other hand, glucocorticoids are important for the maintenance of cartilage homeostasis, and are also used in the process of chondrogenic differentiation of MSCs in vitro (Florine et al., 2013; Randua et al., 2013; Jakobsen et al., 2014).

The response to Glycosaminoglycan was slight in the HA/TA Group, but negative in the HA Group. However, MSCs submitted to chondrogenic differentiation in an enriched hydroxyapatite scaffold environment resulted in increased staining of the Glycosaminoglycan compared to the control at day 9 of differentiation (Wu et al., 2010). Another study also observed Glycosaminoglycan accumulation in the HA hydrogels with MSCs (Zhu et al., 2014). Among the factors that may have influenced Glycosaminoglycan production are HA presentation, which was liquid and not by scaffold, and the fact that the cells were not initially centrifuged. A study on in vitro cartilage formation by human MSCs mentioned that chondrogenesis can be induced by artificially condensing the cells by centrifugation (Sekiya et al., 2002).
The type II collagen expression in the cytoplasmic level showed moderate increase in the Control Group, slight elevation in the TA and HA groups, and no increase in the HA/TA Group. This suggests an adverse effect on type II collagen caused by the medications, which may be related to medication concentration or even continuous exposure. Another hypothesis is that the expression of hypertrophic markers like type $\mathrm{X}$ collagen is higher in MSCs differentiated in a pellet culturing system (Yang et al., 2004). A study on the effects of various glucocorticoids (dexamethasone, prednisolone, triamcinolone) on cultured equine chondrocytes found that glucocorticoids affect numerous genes involved in the cartilage matrix and low doses cause minimum negative effects on the ECM degenerative process (Richardson and Dodge, 2003). However, the use of intraarticular TA in horses decreased expression of type II collagen in synovial fluid (Céleste et al., 2005).

On the other hand, ECM was positively stained by type II collagen in all groups, in which the HA/TA Group was intensely stained, the HA Group moderately and the other groups slightly. A study showed that incorporation of HA methacrylate into human chondrocytes encapsulated in gelatin-methacrylamide hydrogels produced more rounded cell morphologies, enhanced chondrogenesis, increased quantity and distribution of the newly synthesized ECM, and high-intensity staining by type II collagen. It has been suggested that hyaluronic acid methacrylate can be a potent modulator of differentiation (Levett et al., 2014).

The current study presented some limitations, most significantly the non-evaluation of the genetic panel by PCR testing. Additionally, the low number of samples may have influenced the statistical analysis. Although the main goal of the study was to test the medications in their original formulations for intra-articular administration, a different approach would be to incorporate them in a scaffold. 
In conclusion, histological analysis reveals that HA stimulates chondrocyte-like morphology in the different groups, but with low expression of specific cartilage molecules; TA increases the formation of a more homogeneous and organized extracellular matrix.

\section{Declarations}

\section{Conflicts of interest}

The authors declare they have no conflicts of interest with regards to the work presented in this report.

\section{Author contribution}

Pablo Ocampo and Viviana Vallejo were responsible for the conceptualization, methodology, data curation, writing and preparation of the original draft, and the design and conception of the study; Maurico Montoya and Noeme Rocha critically reviewed and supervised the experiment. Fernanda Landim and Sheila Rahal administered the project, wrote, and reviewed the paper.

\section{References}

Amaral AS. Tumor venéreo transmissível canino: critérios citológicos de malignidade e caracterização citomorfológica correlacionada a imunocitoquímica e lesões de DNA. Tese de Doutorado em Medicina Veterinária, Faculdade de Medicina Veterinária e Zootecnia, Universidade Estadual Paulista, Botucatu. 228p. 2005. URL: http://hdl.handle.net/11449/101297

Awad HA, Wickham MQ, Leddy HA, Gimble JM, Guilak, F. Chondrogenic differentiation of adipose-derived adult stem cells in agarose, alginate, and gelatin scaffolds. Biomaterials 2004; 25(16):3211-3222. DOI: https://doi.org/10.1016/j.biomaterials.2003.10.045

Baksh D, Song L, Tuan RS. Adult mesenchymal stem cells: characterization, differentiation, and application in cell and gene therapy. J Cell Mol Med 2004; 8(3):301-316. DOI: https://doi.org/10.1111/j.1582-4934.2004.tb00320.x
Bhumiratana S, Eton RE, Oungoulian SR, Wan LQ, Ateshian GA, Vunjak-Novakovic G. Large, stratified, and mechanically functional human cartilage grown in vitro by mesenchymal condensation. Proc Natl Acad Sci USA 2014; 111(19):6940-6945. DOI: https://doi.org/10.1073/pnas.1324050111

Bowman S, Awad ME, Hamrick MW, Hunter M, Fulzele S. Recent advances in hyaluronic acid based therapyforosteoarthritis. CTM2018;7(1):6. DOI: https://doi.org/10.1186/s40169-017-0180-3

Céleste C, Ionescu M, Poole AR, Laverty S. Repeated intraarticular injections of triamcinolone acetonide alter cartilage matrix metabolism measured by biomarkers in synovial fluid. J Orthop Res 2005; 23(3):602-610. DOI: https://doi.org/10.1016/j.orthres.2004.10.003

Chung J, Song M, Ha CW, Kim JA, Lee CH, Park YB. Comparison of articular cartilage repair with different hydrogel-human umbilical cord bloodderived mesenchymal stem cell composites in a ratmodel. Stem CellRes Ther 2014; 5(2):39.DOI: https://doi.org/10.1186/scrt427

Florine EM, Miller RE, Porter RM, Evans CH, KurzB, GrodzinskyAJ.Effects ofdexamethasone on mesenchymal stromal cell chondrogenesis and aggrecanase activity: comparison of agarose and self-assembling peptide scaffolds. Cartilage 2013; 4(1):63-74. DOI: https://dx.doi.org/10.1177\%2F1947603512455196

Fox SM. Chronic pain in small animal medicine. London: Manson Pub; 2010.

Freshney RI. Culture of animal cells: A manual of basic technique and specialized applications. New Jersey: John Wiley \& Sons; 2010. DOI: https://doi.org/10.1002/9780470649367

Goldberg VM, Goldberg L. Intra-articular hyaluronans: the treatment of knee pain in osteoarthritis. J Pain Res 2010; 3:51-56. DOI: https://doi.org/10.2147/jpr.s4733 
Golding D, Brock J, Whiting B, Lee PYF. Intraarticular injections for management of knee osteoarthritis. J Arthritis 2017; 6(3):1-4. DOI: https://doi.org/10.4172/2167-7921.1000242

Goldring MB. Articular cartilage degradation in osteoarthritis. HSS J 2012; 8(1):7-9. DOI: https://doi.org/10.1007/s11420-011-9250-z

Goodrich LR, Nixon JN. Medical treatment of osteoarthritis in the horse - a review. Vet J 2006; 171(1): 51-69. DOI: https://doi.org/10.1016/j.tvj1.2004.07.008

Grodzinsky AJ, Wang Y, Kakar S, Vrahas MS, Evans CH. Intra $\square$ articular dexamethasone to inhibit the development of post $\square$ traumatic osteoarthritis. J Orthop Res 2017; 35(3):406-411. DOI: https://doi.org/10.1002/jor.23295

Hart LE. In knee OA, intraarticular triamcinolone increased cartilage loss and did not differ from saline for knee pain. Ann Intern Med. 2017; 167:JC27. DOI: https://doi.org/10.7326/ACPJC-2017-167-6-027

Hepper CT, Halvorson JJ, Duncan ST, Gregory AJ, Dunn WR, Spindler KP. The efficacy and duration of intra-articular corticosteroid injection for knee osteoarthritis: a systematic review of level I studies. J Am Acad Orthop Surg 2009; 17(10):638-646. DOI: https://doi:10.5435/00124635-200910000-00006

Jakobsen RB, Østrup E, Zhang X, Mikkelsen TS, Brinchmann JE. Analysis of the effects of five factors relevant to in vitro chondrogenesis of human mesenchymal stem cells using factorial design and high throughput mRNAprofiling. PLoS One 2014; 9(5):e96615. DOI: https://doi.org/10.1371/journal.pone.0096615

Jansen I, Tellegen A, Tryfonidou M, Öner C, Saris D, Woike N, Creemers L. Brief exposure to triamcinolone acetonide, but not its continous presence, strongly inhibits cartilage regeneration by chondrocytes. Osteoarthritis Cartilage 2016; 24:S337. DOI: https://doi.org/10.1016/j.joca.2016.01.606
Jo CH, Lee YG, Shin WH, Kim H, Chai, JW, Jeong EC, Kim J, Shim H, Shin I, Ra JC, Oh S, Yoon K. Intra-articular injection of mesenchymal stem cells for the treatment of osteoarthritis of the knee: a proof $\square$ of $\square$ concept clinical trial. Stem Cells 2014; 32(5):1254-1266. DOI: https://doi.org/10.1002/stem.1634

Larson CM, Kelley SS, Blackwood AD, Banes AJ, Lee GM. Retention of the native chondrocyte pericellular matrix results in significantly improved matrix production. Matrix Biol 2002; 21(4):349-359. DOI: https://doi.org/10.1016/S0945-053X(02)00026-4

Legré-Boyer V. Viscosupplementation: techniques, indications, results. Orthop Traumatol Surg Res 2015; 101(1):S101-S108. DOI: https://doi.org/10.1016/j.otsr.2014.07.027

Levett PA, Melchels FP, Schrobback K, Hutmacher DW, Malda J, Klein TJ. A Biomimetic extracellular matrix for cartilage tissue engineering centered on photocurable gelatin, hyaluronic acid and chondroitin sulfate. Acta Biomater 2014; 10(1):214-223. DOI: https://doi.org/10.1016/j.actbio.2013.10.005

Lo GH, LaValley M, McAlindon T, Felson DT. Intra-articular hyaluronic acid in treatment of knee osteoarthritis: a meta-analysis. J Am Med Assoc 2003; 290(23):3115-3121. DOI: https://doi.org/10.1001/jama.290.23.3115

Lovati AB, Corradetti B, Consiglio AL, Recordati C, Bonacina E, Bizzaro D, Cremonesi F. Comparison of equine bone marrow, umbilical cord matrix and amniotic fluid-derived progenitor cells. Vet Res Commun 2011; 35(2):103-121. DOI: https://doi.org/10.1007/s11259-010-9457-3

Majeed MH, Sherazi SAA, Bacon D, Bajwa ZH. Pharmacological treatment of pain in osteoarthritis: a descriptive review. Curr Rheumatol Rep 2018; 20(12). DOI: https://doi.org/10.1007/s11926-018-0794-5

Mak J, Jablonski CL, Leonard CA, Dunn JF, Raharjo E, Matyas JR, Biernaskie J, Krawetz RJ. 
Intra-articularinjection of synovialmesenchymal stem cells improves cartilage repair in a mouse injury model. Sci Rep 2016; 6:23076. DOI: https://doi.org/10.1038/srep23076

March L, Cross M, Lo C, Arden N, Gates L, Leyland K, King L. "Osteoarthritis: A serious disease." OARSI.org. 2016. Available at: https://www.oarsi.org/education/oarsiresources/oarsi-white-paper-oa-serious-disease

Matsiko A, Levingstone TJ, Gleeson JP, O'brien FJ. Incorporation of TGF $\square$ Beta 3 within collagen-hyaluronic acid scaffolds improves their chondrogenic potential. Adv Healthc Mater 2015; 4(8):1175-1179. DOI: https://doi.org/10.1002/adhm.201500053

McGeady TA. Quinn PJ, FitzPatrick ES, Ryan MT, Kilroy D, Lonergan P. Veterinary Embryology. Oxford, UK: J.W. \& Sons. 2017.

McIlwraith CW. The use of intraarticular corticosteroids in the horse: what is known on a scientific basis? Equine Vet J 2010; 42(6):563-571. DOI: https://doi.org/10.1111/j.2042-3306.2010.00095.x

McIlwraith CW, Frisbie DD, Kawcak CE. The Horse as a model of naturally occurring osteoarthritis. Bone Joint Res 2012; 1(11):297-309. DOI: https://doi.org/10.1302/2046-3758.111.2000132

Pekarek B, Osher L, Buck S, Bowen M. Intraarticular corticosteroid injections: a critical literature review with up-to-date findings. Foot (Edinb) 2011; 21(2):66-70. DOI: https://doi.org/10.1016/j.foot.2010.12.001

Randau TM, Schildberg FA, Alini M, Wimmer MD, Haddouti EM, Gravius S, Stoddart MJ. The effect of dexamethasone and triiodothyronine on terminal differentiation of primary bovine chondrocytes and chondrogenically differentiated mesenchymal stem cells. PLoS One 2013; 8(8):e72973. DOI: https://doi.org/10.1371/journal.pone.0072973
Richardson DW, Dodge GR. Dosedependent effects of corticosteroids on the expression of matrix-related genes in normal and cytokine-treated articular chondrocytes. IR 2003; 52(1):39-49. DOI: https://doi.org/10.1007/s000110300012

Schuurman W. Harimulyo EB, Gawlitta D, Woodfield TB, Dhert WJ, van Weeren PR, Malda J. Three-dimensional assembly of tissue-engineered cartilage constructs results in cartilaginous tissue formation without retainment of zonal characteristics. J Tissue Eng Regen Med 2016; 10(4):315-324. DOI: https://doi.org/10.1002/term.1726

Sekiya I, Vuoristo JT, Larson BL, Prockop DJ. In Vitro cartilage formation by human adult stem cells from bone marrow stroma defines the sequence of cellular and molecular events during chondrogenesis. Proc Natl Acad Sci USA 2002; 99(7):4397-4402. DOI: https://dx.doi.org/10.1073\%2Fpnas.052716199

Siengdee P, Radeerom T, Kuanoon S, Euppayo T, Pradit W, Chomdej S, Ongchai S, Nganvongpanit K. Effects of corticosteroids and their combinations with hyaluronanon on the biochemical properties of porcine cartilage explants. BMC Vet Res 2015; 11(1):1-11. DOI: https://dx.doi.org/10.1186\%2Fs12917-015-0611-6

Silvinato A, Bernardo WM. Inflammatory arthritis or osteoarthritis of the knee - Efficacy of intra-joint infiltration of methylprednisolone acetate versus triamcinolone acetonide or triamcinolone hexacetonide. Rev Assoc Med Bras 2017; 63(10):827-836. DOI: https://doi.org/10.1590/1806-9282.63.10.827

Trounson A, McDonald C. Stem cell therapies in clinical trials: progress and challenges. Cell Stem 2015; 17(1):11-22. DOI: https://doi.org/10.1016/j.stem.2015.06.007 
Vaca-González JJ, Gutiérrez ML, GarzónAlvarado DA. Cartílago articular: estructura, patologías y campos eléctricos como alternativa terapéutica. Revisión de conceptos actuales. Rev Colomb Ortop Traumatol 2017; 31(4):202-210. DOI: https://doi.org/10.1016/j.rccot.2017.06.002

Wang CT, Lin J, Chang CJ, Lin YT, Hou SM. Therapeutic effects of hyaluronic acid on osteoarthritis of the knee: a meta-analysis of randomized controlled trials. J Bone Joint Surg Am 2004; 86(3):538-45. DOI: https://doi.org/10.2106/00004623-200403000$\underline{00012}$

Wernecke C, Braun HJ, Dragoo JL. The effects of intra-articular corticosteroids on articular cartilage. Orthop J Sports Med 2015; 3(5):2325967115581163. DOI: https://doi.org/10.1177/2325967115581163

Wu SC, Chang JK, Wang CK, Wang GJ, Ho ML. Enhancement of chondrogenesis of human adipose derived stem cells in a hyaluronan-enrichedmicroen- vironment. Biomaterials 2010;31(4):631-640. DOI: https://doi.org/10.1016/j.biomaterials.2009.09.089

Yang IH, Kim SH, Kim YH, Sun HJ, Kim SJ, Lee JW. Comparison of phenotypic characterization between 'alginate bead' and 'pellet' culture systems as chondrogenic differentiation models for human mesencgymal stem cells. Yonsei Med J 2004; 45(5):891-900. DOI: https://doi.org/10.3349/ymj.2004.45.5.891

Zhang Z, McCaffery JM, Spencer RG, Francomano CA. Hyaline Cartilage engineered by chondrocytes in pellet culture: histological, immunohistochemical and ultrastructural analysis in comparison with cartilage explants. J Anat 2004; 205(3):229-37. DOI: https://doi.org/10.1111/j.0021-8782.2004.00327.x

Zhu M, Feng Q, Bian L. Differential effect of hypoxia on human mesenchymal stem cell chondrogenesis and hypertrophy in hyaluronic acid hydrogels. Acta biomaterialia 2014; 10(3):1333-1340.DOI: https://doi.org/10.1016/j.actbio.2013.12.015 